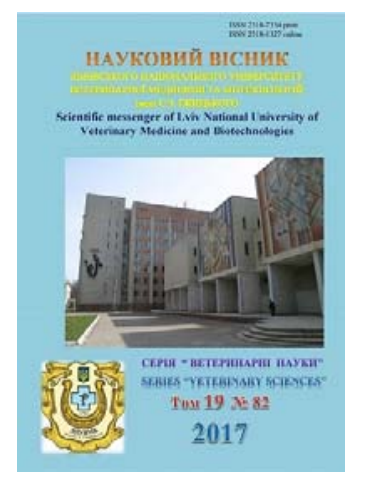

Науковий вісник Львівського національного університету ветеринарної медицини та біотехнологій імені С.З. Гжицького

Scientific Messenger of Lviv National University of Veterinary Medicine and Biotechnologies

doi:10.15421/nvlvet8204

ISSN 2518-7554 print

ISSN 2518-1327 online

$\underline{\text { http://nvlvet.com.ua/ }}$

УДК 619: $618.36: 636.1$

\title{
Передчасне відшарування плаценти коней (діагностика, лікування)
}

\author{
В.I. Бородиня, О.А. Святченко \\ borodynia@gmail.com \\ Наџіональний університет біоресурсів і природокористування Украӥни, \\ вул. Героїв Оборони, 15, м. Київ, 03041, Украӥна
}

\begin{abstract}
За передчасного відшарування плащенти діагностичні дослідження потрібно проводити оперативно, оскільки від иього залежить життя і життездатність новонародженого. Загальний стан роділлі зазвичай без будь-яких відхилень від норми. Клініко-акушерське обстеження включає піхвове і сонографічне дослідження. Завдяки вагінальному дослідженню можливо побачити відкриту шийку матки та випалу плаценту. Сонографія матки дозволяє визначити місиезнаходження відшарованої ділянки плаценти, ї̈ обсяг. Характерні симптоми передчасного відшарування плаценти у кобили стають помітними лише під час жеребіння. Для родів з передлежанням плаценти характерним є відсутність виливання навколоплідних рідин (алантоїсної рідини) на початку другої стадії родів, оскільки хоріоалантоїс залишається ичілісним. Лоша, всі оболонки і води, вміщені в иілісний хоріоалантоїс, виходять одночасно. На плодових оболонках дуже чітко помітні структурні зміни. Даний патологічний стан значно впливає на стан лошати в неонатальний період. Для самої кобили роди з діагнозом передчасного відмарування плаценти не становлять ніякої небезпеки. Одним з найважливіших моментів у наданні допомоги є негайне розтинання хоріоалантоїсу і виведення плода назовні.

Ключові слова: коні, кобили, дисточія, передчасне відщарування плаценти, діагностика, лікування.
\end{abstract}

\section{Преждевременная отслойка плаценты лошадей (диагностика, лечение)}

\author{
В.И. Бородыня, О.А. Святченко \\ borodynia@gmail.com \\ Национальный университет биоресурсов и природопользования Украины, \\ ул. Героев Обороны, 15, Киев, 03041, Украина
}

\begin{abstract}
При преждевременной отслойке плаченты диагностические исследования нужно проводить оперативно, так как от этого зависит жизнь и жизнеспособность новорожденного. Общее состояние роженииы обычно без каких-либо отклонений от нормы. Клинико-акушерское обследование включает влагалищное и сонографическое исследования. Благодаря вагинальному исследованию можно увидеть открытую шейку матки и выпавщую плаченту. Сонография матки позволяет определить местонахождение отслоивщегося участка плаченты, его величину. Характерные симптомы преждевременной отслойки плаценты у кобылы становятся заметными только во время выжеребки. Для родов с предлежсанием плаценты характерно отсутствие вытекания околоплодной жидкости (алантоисной жидкости) в начале второй стадии родов, поскольку хориоаллантоис остается иелостным. Жеребенок, все оболочки и воды, помещенные в иелостный хориоалантоис, выходят одновременно. На плодовых оболочках очень четко заметны структурные изменения. Данное патологическое состояние оказывает значительное воздействие на жеребенка в неонатальный период. Для самой кобылы роды с диагнозом преждевременной отслойки плаценты не представляют никакой опасности. Одним из важнейших моментов при оказании помощи является немедленное вскрытие хориоаллантоиса и выведение плода нару-

Ключевые слова: лочади, кобыль, дисточия, преждевременная отслойка плаценты, диагностика, лечение.
\end{abstract} жу.

Citation:

Borodynia, V.I., Svyatchenko, O.A. (2017). Premature placental abruption in horses (diagnosis, treatment). Scientific Messenger LNUVMB, 19(82), $16-20$. 


\title{
Premature placental abruption in horses (diagnosis, treatment)
}

\author{
V.I. Borodynia, O.A. Svyatchenko \\ borodynia@gmail.com \\ National University of Life and Environmental Sciences of Ukraine, \\ Heroyiv Oborony Str., 15, Kyiv, 03041, Ukraine
}

In case of a premature placenta abruption, diagnostics should be done quickly, because it affects survival and viability of a foal. Premature detachment of the placenta in the mares, which occurs before or during birth, is not a common parable. This pathological condition ranges from 5 to $10 \%$ of all cases of abortion, the birth of dead fetuses and perinatal mortality in horses. The general condition of a mare usually is without any abnormalities. Clinical obstetric examination includes vaginal and sonographic study. When conducting a vaginal examination, it is possible to see an open cervix and placenta bulging in a vagina. Sonography of an uterus enables to determine location of the placenta abruption and its volume. Typical symptoms of a premature abruption of a placenta in mares become visible only when foaling. For foaling with placenta previa typical is absence of ejection of amniotic fluid (allantois fluid) at the beginning of the second stage of foaling as chorioallantois remains intact. Fetus, all shells and fluids that are contained in a holistic chorioallantois, come out at once. In afterbirth of mares with premature placental abruption changes in structure of membranes are clearly observed. This pathological condition may significantly influence the unborn foal in the neonatal period. For mares, foaling with a diagnosis of premature placental abruption does not pose any danger. One of the most important factors in treatment is immediate dissection of chorioallantois and evacuating the fetus.

Key words: horses, mares, dystocia, premature placental abruption, diagnostics, treatment.

\section{Вступ}

На думку науковців і фахівців ветеринарної медицини, передчасне відшарування плаценти у кобил, яке виникає до або під час жеребіння, не є поширеною патологією. Даний патологічний стан складає від 5 до $10 \%$ усіх випадків переривання вагітності, народження мертвих плодів і перинатальної смертності у коней (King, 2001; McCue, 2009; Bevis, 2016).

Порушення з'єднання плацентарних оболонок зі стінкою матки (а саме з їі слизовою оболонкою), яке стається під час першої, підготовчої стадії і другої, власне родової стадії жеребіння, є небезпечним насамперед для життя і життєздатності плода. Проте передчасне відшарування плаценти під час жеребіння у ветеринарній медичній літературі значною мірою лишається не висвітленим i потребує детального опрацювання й узагальнення (Yablonskyi et al., 2006; Kähn, 2017).

Передчасне відшарування плаценти від слизової матки становить серйозну загрозу життю плода, оскільки воно припиняє надходження кисню до лошати. Плацента, за участі якої лоша забезпечується киснем впродовж усієї вагітності, більше не функціонує через порушення зв'язку між хоріоалантоїсом і слизовою оболонкою матки. У разі передчасного відділення плаценти плід опиняється перед безпосередньою загрозою асфіксії.

Лоша при спробі дихати буде вдихати тільки рідину, а не повітря. Для збереження життя та життєздатності воно повинно бути виведене $з$ родового каналу максимально швидко. Більшість лошат, народжених у патологічних родах 3 діагнозом передчасного відшарування плаценти, мають певний рівень загрози щодо подальшого життя і можуть бути нежиттєздатними (Lacey, 2017).

Передчасне відділення плаценти відбувається часто в поєднанні з плацентарною інфекцією. Хронічне відшарування плаценти від слизової оболонки матки може відбуватися за декілька днів або тижнів до за- кінчення жеребності як наслідок плацентиту. Такий патологічний стан може бути також пов'язаний 3 розслабленням шийки матка або незначною кровотечею із вульви (McCue, 2009; Lacey, 2017).

Передчасне відділення плаценти є одним із симптомів отруєння алкалоїдами гриба Claviceps purpurea маткових ріжків, який уражає до 170 видів культурних і дикорослих злаків, які поїдають коні (Lacey, 2017).

Мета $і$ завдання дослідження. Всебічне опрацювання і проведення аналізу даних літератури щодо діагностики, лікування і профілактики передчасного відшарування плаценти у коней під час жеребіння та їх узагальнення.

\section{Матеріал і методи дослідження}

У процесі дослідження було використано такі методи дослідження, як пошук, опрацювання, аналіз літературних джерел щодо діагностики, лікування i профілактики передчасного відшарування плаценти у коней під час жеребіння та узагальнення їх даних.

\section{Результати та їх обговорення}

За даними клінічного дослідження кобил з випадками передчасного відшарування плаценти було встановлено, що середня тривалість вагітності у них склала 334 дні. Діапазон коливався в межах 321-341 день. (Schmidt, 2017). За декілька тижнів до жеребіння проявляються ознаки, що можуть вказати на передчасне відшарування плаценти. Викликає тривогу передчасна поява молока, рідкі вагінальні виділення і занадто сильні рухи плода. Завдяки вагінальному дослідженню можливо побачити відкриту шийку матки та випалу плаценту (Kähn, 2017).

Найчастіше за все характерні симптоми передчасного відшарування плаценти у кобили стають помітними лише під час жеребіння. Для родів 3 передлежанням плаценти характерним є відсутність виливан- 
ня навколоплідних рідин (алантоїсної рідини) на початку другої стадії родів, оскільки хоріоалантоїс залишається цілісним. Натомість перше, що видно під час клінічного дослідження, це випинання маси тканин яскраво-червоного кольору. Плацента більше не прикріплюється до матки. Плід, всі оболонки і води, вміщені в цілісний хоріоалантоїс, виходять одночасно. Лоша, яке буде намагатися дихати, вдихатиме рідини. Цікаво, що амніотична рідина, яка зазвичай виливається назовні на початку родової стадії перед народженням плода, за передлежання плаценти виходить після ії̈ виведення (Schmidt, 2017).

У вульві цегельно-червоного (фіолетового) кольору хоріоалантоїсна оболонка під час другої стадії родів часто залишається цілісною довше, ніж за нормальних родів і випинає (через тиск амніотичних вод) назовні у вигляді червоного мішка. На ньому, звисаючому з вульви, подібному до надувної кулі з мікроворсинками, оксамитового вигляду, видно зіркоподібну структуру, вільну від ворсинок, яка $є$ значно світлішою i через це добре помітною на тлі пурпурночервоного хоріону. В даному випадку мова йде про ту частину хоріона, до якої дотичне внутрішне війся шийки матки. У цій ділянці, яка характеризується великою кількістю контактів з ендометрієм, ворсинки не утворюються і через це виникають світліші зіркоподібні ділянки порівняно з цегельно-червоним хоріоном («шийкова зірка») (Кӓhn, 2017).

Передлежання плаценти може призвести до значного впливу на ненароджене лоша в неонатальний період. В основному відшарування плаценти призводить до порушення обміну речовин між плодом і материнським організмом. У плода на першому місці стоїть недостатнє забезпечення киснем, недостатня віддача вуглекислого газу та неадекватне збільшення концентрації сечових компонентів 3 креатинами та сечовиною.

У ослаблених лошат відмічають численні наслідки передчасного відшарування плаценти. Діагностують різні форми пригнічення дихання, різноманітні ускладнення неонатальної дезадаптації, дослідження артеріальної крові на вміст газів в основному показує чітку гіпоксію і гіперкапнію (Kähn, 2017).

У деяких лошат було встановлено постнатальну дисфункцію сечового міхура. Біохімічним аналізом крові у них були виявлені характерні ознаки передчасного відшарування плаценти. Кількість креатиніну (1 мг/дл $=88,4$ ммоль/л; 1 ммоль/л $=0,01312$ мг/дл) у новонароджених лошат від кобил 3 відшаруванням плаценти була значно вищою від нормальної. В перші 24 години після народження середня концентрація креатиніну лошат була в межах 5-6 мг/дл (442530 ммоль/л), при тому що найвища гранично допустима концентрація у нормальних лошат досягає лише від 2,1 до 16,2 мг/дл (186-1432 ммоль/л). У наступні дні вміст креатиніну поступово відчутно знизився i наблизився до нормальної концентрації приблизно до кінця першого тижня життя. За даними проведених досліджень, гіпоглікемія спостерігалася в 50\% досліджених лошат, у яких можна було визначити вміст глюкози при потраплянні в клініку. У лошат з гіпоглі- кемією концентрація глюкози в крові була в межах від 52 до 92 мг/дл (Kähn, 2017).

Діагноз на передчасне відшарування плаценти може бути визначений за допомогою ультразвукового дослідження вагітної матки. Сонографія матки дозволяє визначити місцезнаходження відшарованої ділянки плаценти, іiі обсяг. Це можна підтвердити УЗД через черевну стінку чи ректально (Maryann and Cerullo, 2011; Kähn, 2017).

Кобили з високим рівнем ризику щодо передчасного відшарування плаценти, які раніше мали аборт, мертвонароджених або слабких лошат повинні бути досліджені на пізніх термінах вагітності з допомогою ультразвуку для своєчасного виявлення плацентиту або потовщення плаценти. Мінімальна комплексна товщина плаценти і матки (КТПМ) у здорових кобил повинна складати 7,1 $\pm 1,6$ мм, а максимальна $-11,5 \pm$ 2,4 мм. Дослідження показали, що у кобил з високими показниками КТПМ завжди народжуються лошата 3 патологіями. Показник КТПМ > 17,5 мм вже свідчить про плацентит (Schmidt, 2017).

Огляд і оцінка плодових оболонок повинна бути обов'язковою процедурою у коней після жеребіння. Оболонки повинні бути досліджені, щоб гарантувати, що вони були відділені від слизової оболонки матки і вигнані назовні в повному обсязі. Неповне відділення плодових оболонок, найчастіше 3 невагітного рогу, може призвести до серйозних наслідків, таких як метрит, ендотоксемія і ламініт (якщо залишити породіллю без належного нагляду i клініко-акушерського дослідження) (Samper and Plough, 2012).

Варто зауважити, що навіть своєчасно і правильно діагностоване передчасне відшарування плаценти i надання кваліфікованої допомоги не виключає загрози життєздатності новонародженого лоша (Schmidt, 2017).

У коней під час фізіологічної вагітності та в першу й другу стадії родів плацента не повинна від’єднуватися від слизової оболонки матки. Її відділення від матки в нормі відбувається у третю (послідову) стадію жеребіння. В нормі хоріоалантоїс досить тонка оболонка і легко розривається під час родів (найчастіше в ділянці шийкової зірки), що дає можливість вийти першим назовні плоду, оточеному амніотичною оболонкою. Однак бувають випадки, коли плацента виганяється передчасно.

3 виникненням запалення плаценти iï стінка набрякає, потовщується, між хоріоном і стінкою матки накопичується ексудат, який відтісняє плаценту від стінки матки. У потовщеній, набряклій плаценті, за хронічного перебігу відбувається розростання сполучної тканини, внаслідок чого та стає більш щільною, міцною і жорсткою. У тих випадках, коли плацента потовщується внаслідок плацентиту, це призводить до передчасного іiі відшарування. Ворсинки хоріону виходять $з$ крипт слизової оболонки матки, плацентарний зв'язок між плодом і матір'ю перестає існувати і відповідно живлення плода припиняється. До його організму більше не надходять кисень та поживні речовини. Виникає пряма загроза життю плода (Schmidt, 2017). 
Якщо значна частина хоріона відокремлюється передчасно від стінки матки, у лоша починають відбуватися гипоксичні процеси, плід зазнає стресу, відбувається вивільнення меконию, а в найважчих випадках - смерть плода (Samper and Plough, 2012).

Збереження цілісності зовнішньої плацентарної оболонки під час жеребіння і подальше порушення зв'язку матки та плаценти призводять до швидкого зниження транспортування кисню до плода. Як наслідок, він може постраждати через відсутність кисню (гіпоксію) або померти від задухи, якщо такий стан триває або прогресує. Через це, як тільки діагностують передчасне відшарування плаценти, надавати допомогу необхідно швидко для запобігання народження мертвого або ослабленого лошати.

Відразу після того, як народжується лоша, виникає ще одна екстремальна ситуація. Крім нестачі кисню, про що було зазначено попередньо, для новонародженого лошати існує ще одна серйозна небезпека, пов'язана 3 передчасним відділенням плаценти - це сепсис. Його загроза виникає завжди, коли діагностують патологічне жеребіння. Відразу після народження лоша, як і раніше, безпосередньо з'єднане пуповиною 3 плацентою і бактерії з повітря та приміщення інфікують іiі. Виникає сепсис, коли бактерії потрапляють в організм лошати через інфіковану плаценту чи пуповину до іiі дезінфекції або до одержання лошам молозива. Тому надзвичайно важливим $є$ уважне спостереження за станом лошати у його перші 24-48 годин (Maryann and Cerullo, 2011).

Для самої кобили роди 3 діагнозом передчасного відшарування плаценти не становлять ніякої небезпеки, якщо тільки лоша не розташоване неправильно в родовому каналі. Внаслідок зазначеної патології для кобили немає суттєвих ризиків, крім можливості виникнення звичайних гематом, розривів піхви, переддвер'я, вульви тощо, які зазвичай залежать від розміру лошати, що народилося. Для кобили не існує будьякого ризику щодо майбутніх жеребностей після родів 3 передчасним відшаруванням плаценти. Відтворювальна здатність кобили зазвичай зберігається (King, 2001).

Своєчасне визначення діагнозу передчасного відшарування плаценти і негайне, кваліфіковане втручання з метою надання допомоги є ключовими факторами для виживання лошати. Очевидно, що за передчасного відшарування плаценти брак кисню або кисневе голодування занадто тривалий період часу може мати серйозні, а іноді й смертельні наслідки для нього (King, 2001; Maryann and Cerullo, 2011).

Таким чином, якщо лоша, що перебуває всередині товстої, міцної плаценти, не зможе їі розірвати - загине. Але якщо йому буде оперативно надана допомогти, його життя зазвичай може бути збережене.

Одним 3 найважчих і найважливіших моментів у наданні допомоги за діагнозу передчасне відшарування плаценти є негайне розтинання хоріоалантоїсу. Він потовщений, жорсткий, міцний і слизький, його майже неможливо розірвати лише руками, без використання акушерських інструментів. Для цього можна використати ніж з акушерського набору або скальпель, але слід пам'ятати, що розтинання хоріоалантої- су виконувати потрібно так, щоб це було безпечним для здоров'я кобили та лошати. Для розтинання плаценти також використовують хірургічні ножиці (Maryann and Cerullo, 2011).

Як тільки визначено діагноз передчасного відшарування плаценти, необхідно терміново хірургічними ножицями розітнути хоріоалантоїс. Всередині під ним буде білого кольору амніон. Останній теж швидко і дуже обережно розітнути, щоб не ушкодити плід, який розміщується впритул під ним. Переконатися, що в родовому каналі передлежать обидві кінцівки і голівка плода. Амніотичну оболонку розкрити і якомога швидше під час перейм і потуг вивести плід назовні, оскільки він має брак кисню через раннє відділення плаценти, але не травмувати кобилу в процесі надання допомоги. Лоша повинно бути уважно обстежене на наявність ознак гіпоксії (кисневого голодування) або інфекції. Потрібно пам'ятати, що тягнути лоша треба завжди вниз до п'яткових горбів тазових кінцівок кобили, а не прямо. Не чекати, поки кобила самостійно народить лоша, адже воно не отримує кисню і може загинути.

Через загрозу виникнення сепсису надзвичайно важливо розірвати пупковий канатик якомога швидше після виведення плода 3 родового каналу, негайно занурити куксу пуповини у знезаражуючий розчин i повторити таку маніпуляцію кілька разів протягом перших кількох годин життя лошати. Ось чому під час лікування лошати після народження із діагнозом передчасне відшарування плаценти обов'язковим $\epsilon$ внутрішньовенне застосовування антибіотиків, а також щоденний контроль показників крові на наявність ознак інфекції (Maryann and Cerullo, 2011).

Відразу після виведення новонародженого з родового каналу назовні його грудна клітка більше не здавлюється в родовому каналі й він починає дихати. Необхідно в цьому переконатися. Будуть чутні звуки булькання рідини, яку лоша вдихнуло. Обережно витискають частину рідини 3 носових ходів, утримуючи його перенісся між великим і вказівним пальцями та рухаючи рукою вниз у напрямку до його ніздрів. Для більш повного видалення рідини користуються чистим рушником. Потрібно стимулювати лоша, енергійно витираючи його і подразнюючи чутливе місце на середині його спини. Воно повинно намагатися підняти голову. Якщо лоша ще не дихає добре або ще відчутні звуки булькання, потрібно підняти (з помічником) лоша за тазові кінцівки й утримувати його в такому положенні для максимально повного витоку рідини з його легенів. Продовжувати стимулювати лоша потрібно доти, доки його дихання не поліпшиться і воно почне намагатися встати на кінцівки. Підтягнути новонароджене до кобили, так щоб вона могла стимулювати його сама. Але не припиняти уважно спостерігати за ним.

У центрі уваги цього захворювання через передчасне відшарування плаценти - дихальна недостатність у формі гіпоксії та гіперкапнії. Початкове лікування при гіпоксії складалося з введення кисню інтраназально через зонд. У важких випадках дихання здійснюють через назотрахеальний тубус (Kähn, 2017). 
Лікування азотемії проводять інфузотерапією. До стандартного лікування належать також ін'єкції дофамину (1-5 мг/кг/хв.) (Kähn, 2017).

Лошатам 3 ушкодженням ЦНС з ознаками неонатального синдрому дезадаптації кровообігу призначають в/в диметилсульфоксид (DMSO) у дозах 1 г/кг маси тіла 1-2 рази на добу в $10-20 \%$ розчині (з фізрозчином) (Кӓhn, 2017).

Усім новонародженим лошатам від кобил, що мали діагноз патологічних родів «передчасне відшарування плаценти», необхідно надавати належну інтенсивну терапію.

\section{Висновки}

Передчасне відшарування плаценти у кобил, яке виникає до або під час жеребіння, не $є$ поширеною патологією. Даний патологічний стан складає від 5 до $10 \%$ усіх випадків переривання вагітності, народження мертвих плодів і перинатальної смертності у коней. Передчасне відшарування плаценти від слизової матки становить серйозну загрозу життю плода. Характерні симптоми передчасного відшарування плаценти у кобили найчастіше стають помітними лише під час жеребіння. За передчасного відшарування плаценти діагностичні дослідження потрібно проводити оперативно, оскільки від цього залежить життя і життєздатність новонародженого. Клініко-акушерське обстеження включає піхвове і сонографічне дослідження. Усім новонародженим лошатам від кобил, що мали діагноз патологічних родів «передчасне відшарування плаценти» необхідно надавати належну інтенсивну терапію.

\section{Бібліографічні посилання}

McCue, P.M. (2009). Red bag - a foaling emergency. Available at: http://csu-cvmbs.colostate.edu/ Documents/Learnmares34-pregfoal-redbag-apr09.pdf
King, M. (2001). Foaling problems. Available at : http://www.thehorse.com/articles/12744/foalingproblems

Bevis, B. (2016). Dangers of the dreaded red bag delivery. Available at: http://www.equinechronicle. com/dangers-of-the-dreaded-red-bag-delivery/

Yablonskyi, V.A., Khomyn, S.P., Kalynovskyi, H.M., Kharuta, H.H. (2006). Veterynarne akusherstvo, hinekolohiia ta biotekhnolohiia vidtvorennia tvaryn. Vinnytsia: Nova knyha (in Ukrainian).

Kähn, W. (2017). Die vorzeitige lã-sung der plazenta beim pferd: symptome bei der stute, auswirkugnen auf das fohlen. Available at : http://www.tierklinikhochmoor.de/index.php?id=58

Lacey, F.M. (2017). «Red bag» delivery. Available at: http://ogec.com.au/red-bag-delivery

Schmidt, A. (2017). Red bag delivery. Available at: http://www.horsechannel.com/horse-health/red-bagdelivery.aspx

What to expect when you're expecting... (2011). Available at: http://www.hendersonequineclinic.com/ourblog/2011/2/18/what-to-expect-when-youreexpecting.html

Maryann, L., Cerullo, B. (2011). Red bag or placenta previa birth. Available at: http://www. miniatureventures.com/redbag.html

Samper, J.C., Plough, T.A. (2012). How to Deal With Dystocia and Retained Placenta in the Field. AAEP PROCEEDINGS. 58, 359-361.

Received 21.09.2017 Received in revised form 20.10.2017 Accepted 26.10.2017 